\title{
A survey for potentially zoonotic gastrointestinal parasites in domestic cavies in Cameroon (Central Africa)
}

Felix Meutchieye ${ }^{1}$, Marc K. Kouam ${ }^{1,2^{*}}$ D, Emile Miegoué ${ }^{1}$, Terence T. Nguafack', Joseph Tchoumboué Alexis Téguia ${ }^{1}$ and Georgios Théodoropoulos ${ }^{3}$

\begin{abstract}
Background: Farm animals are usually suspected to transmit infections to humans. Domestic cavies (Cavia porcellus) are hosts to a variety of pathogens, some of which are zoonotic. Several parasites including the protozoa Giardia spp. and Cryptosporidium spp. may be causative agents of gastrointestinal disorders in domestic cavies and humans. The aim of the study was to investigate the occurrence of potentially zoonotic protozoa as well as any potential zoonotic gastrointestinal parasite in domestic cavies raised under a semi extensive system in the rural areas of Cameroon.

Results: Giardia/Cryptosporidium antigens were detected in 12.90\% of cavies. Helminthe eggs were found in 1.52\% of animals. The prevalence of Paraspidodera uncinata, Heligmosomoides polygyrus (also known as Nematospiroides dubius) and Trichuris sp. was 1\% (4/397), 0.3\% (1/397), and 0.3\% (1/397), respectively. Presence of Giardia/Cryptosporidium was unrelated to the occurrence of diarrhea, as none of the positive samples was from a diarrheic individual.

Conclusion: Domestic cavies are hosts of Giardia/Cryptosporidium and appear as potential source of human giardiasis, cryptosporidiosis and infection with H. polygyrus in Cameroon. In keeping with the One Health Initiative, veterinarians and medical doctors should collaborate to address the problem of Giardia and Cryptosporidium infection in cavies and cavy breeders both in Cameroon and other countries with a similar cavy breeding system. Follow-up studies are required to further taxonomically characterize these cavy parasites and to determine their routes of transmission to humans.
\end{abstract}

Keywords: Zoonoses, Domestic cavies, Giardia/Cryptosporidium, Cameroon

\section{Background}

Zoonotic hazards have always been a concern to public health officials, animal feed industries, food animal industries and consumers all over the world. The One Heath Initiative, which is a strategy to minimize the global impact of zoonotic and infectious diseases at the animal-human-ecosystem interface through interdisciplinary collaboration, is a response to this shared concern. Cryptosporidium spp. and Giardia spp. are intestinal protozoa parasites recognized as prevalent and widespread enteropathogens of humans and many species of

\footnotetext{
* Correspondence: kouam@crfilmt.org

${ }^{1}$ Department of Animal Production, Faculty of Agronomy and Agricultural Sciences, PO BOX 188, Dschang, Cameroon

${ }^{2}$ Center for Research on Filariases and other Tropical Diseases (CRFilMT), P.O

Box 5797, Yaoundé, Cameroon

Full list of author information is available at the end of the article
}

mammals [1-3]. They are commonly identified in domestic livestock, where they shed large numbers of oocysts and cysts. Contamination of water and food with livestock feces containing Cryptosporidium oocysts and Giardia cysts could occur via routes that span the entire food production continuum $[4,5]$. Outbreaks of water and food borne diseases caused by Cryptosporidium spp. and Giardia spp. are well documented [6], but the role of domestic cavies (Cavia porcellus) commonly known as guinea pigs in the maintenance and transmission of these parasites is poorly reported. Nowadays domestic cavies are no longer limited to a small-scale production for research or game purposes only but have become an important item in the livestock production sector in many countries [7-9]. In Cameroon, the population of cavies is increasing, for instance from 30, 293 to 35, 256 
heads in 2011 and 2012 respectively [10], following the decision of the government to increase the source of income and meat in rural areas through mini-livestock species husbandry such as cavies [11]. With the projected increase in cavy production in the country, there is a concern about the emergence of zoonotic infection especially giardiosis and cryptosporidiosis which have previously been reported in many settings in domestic cavies [12-16]. Furthermore, complaints from farmers on diarrheal stools in both children and cavies during past surveys reinforced the suspicion of the occurrence of these parasites on cavy farms, since Giardia spp. and Cryptosporidium spp. are known to cause diarrhea in children $[2,17,18]$ and cavies [12, 13]. In addition, the environmental burden of Cryptosporidium oocysts and Giardia cysts from fecal waste reported in Cameroon [19-21] urged us to study whether Cryptosporidium and Giardia occur in cavy husbandry in Cameroon, in order to raise awareness of their potential threat on public health and on cavy industry under development. Thus, the main objective of this study was to detect any presence of Giardia, Cryptosporidium or any potential zoonotic gastrointestinal parasite in domestic cavies raised by farmers in the rural areas of the country.

\section{Methods}

\section{Study area and farms}

The study was carried out between June and July 2014 in the western highlands of Cameroon, an agro-ecological zone covering the North West and West administrative regions of the country, located between $5^{\circ} 20^{\prime}-7^{\circ}$ north latitude and $9^{\circ} 40^{\prime}-11^{\circ} 10^{\prime}$ east longitude. The North West and West regions are the largest cavy production zone of the country, and account for $94.1 \%$ of the national production in 2012 [10]. The region is characterized by a high relief, and the climate is of the Sudano-Guinean type. There is one rainy season, from mid March to Mid November and one dry season from mid November to mid March. Humidity varies from 80 to $98 \%$. Annual precipitation ranges from 1500 to $2500 \mathrm{~mm}$ while minimum and maximum temperature are $10{ }^{\circ} \mathrm{C}$ and $34{ }^{\circ} \mathrm{C}$ respectively [22]. The human population is estimated at 1.82 million inhabitants, and is one of the highest population densities in the country, with at least 79 inhabitants per $\mathrm{km} 2$ and a population growth rate of $3.1 \%$ [23].

The study was conducted in privately-owned farms in rural areas of Menoua and Bamboutos border Divisions. Farms are small holder units also keeping rabbits, sheep, goats, or local fowl breeds. The housing system is either the cage system or in most cases, the free kitchen roaming system; in this latter system, cavies share the kitchen floor with the local fowl and/or small ruminants, and feed on kitchen wastes, forages and rarely concentrate. The husbandry system is essentially semi-extensive.

\section{Study design and sample collection}

There is no central registry of farms in Cameroon so private farms were located and visited using a snowball sampling technique whereby a livestock farmer, when located helped to locate the next farm and so on. Fecal samples were randomly collected regardless of any endogenous or exogenous factors such as breed, age, gender, or housing system in a cross sectional survey from village households who owned cavies and wished to participate in the study. Cavies were randomly caught and individually put into a large and clean bucket to defecate. Soon after defecation, individual fecal material from non-diarrhoeic and diarrhoeic cavies was carefully collected into capped, plastic sample containers containing $10 \%$ formalin, then sealed. The sample size of interest was the one to detect a disease in a population. Therefore, the sample size was determined based on the formula for sample size calculation [24] as follows: $\mathrm{n}=\left(1-(1-\mathrm{p})^{1 / \mathrm{d}}\right)^{*}(\mathrm{~N}-(\mathrm{d}-1) / 2)$ where $\mathrm{n}=$ sample size, $\mathrm{p}=$ probability of finding at least one case (95\%), $\mathrm{d}=$ number of cases in the population, and $\mathrm{N}$ the population size. The cavy population size in the West Region was obtained from the Cameroon National Institute of Statistics [10] as 19,948 individuals. A previous study [25] in the area showed an overall prevalence of gastrointestinal parasites to be $12.9 \%$; thus the estimated number of cases (d) in the population was determined as 2574 . Finally, the computed sample size was determined as 22 . However, in order to get some idea of the proportion of infection in the population, the sample size was increased depending on the economical means, to 397 for the parasitological test, and 93 for the serological test.

\section{Cryptosporidium spp. and Giardia spp. antigen detection}

Fecal samples were tested for the presence of specific Giardia and Cryptosporidium specific antigens using a commercial coproantigen ELISA test kit (Chek ${ }^{\circ}$ Giardia/ Cryptosporidium Microplate Assay, Wampole ${ }^{\circ}$ ), according to the manufacturer's instructions. The Giardial Cryptosporidium $\mathrm{Chek}^{\circ}$ is a solid phase immunoassay for the simultaneous detection of Giardia cyst and Cryptosporidium oocyst specific antigen in aqueous extracts of fecal specimens. The test uses monoclonal and polyclonal antibodies to cell-surface antigens of Giardia cyst and an oocyst antigen of Cryptosporidium. The optical density values were obtained using an automatic plate reader (Multiscan RC V1.5.0).

\section{Detection of gastrointestinal parasite eggs/cysts/oocysts in fecal samples}

Fecal samples were analyzed qualitatively using the saturated salt solution $(\mathrm{NaCl})$ as flotation fluid. The simple flotation method was used to detect the parasite eggs, cysts and oocysts which were identified microscopically 
based on morphology and size [26, 27]. Heavy eggs were screened using the simple sedimentation test, as described by Zajac and Conroy [27]. Slides were mounted and examined at 100 and 400 magnifications.

\section{Results}

In total, 397 fecal samples were collected, of which 93 were analyzed for antigen detection. Of these 93 samples $12(12.90 \%)$ were positive. Since the assay simultaneously detect Giardia and Cryptosporidium antigen, these positive samples could be only Giardia or only Cryptosporidium or both Giardia and Cryptosporidium antigens. All the Giardia/Cryptosporidium positive samples were from non-diarrheic individuals.

All the samples collected were analyzed for the presence of eggs, cysts and oocysts of gastrointestinal parasites. Helminthe eggs were detected in 6 (1.52\%) samples. The helminthes found were Paraspidodera uncinata (1\%), Heligmosomoides polygyrus (Syn. N. dubius) (0.3\%) and Trichuris sp. (0.3\%) (Table 1). Cysts of Giardia, oocysts of Cryptosporidium or eggs of tremadodes were not observed in feces.

\section{Discussion}

There was a need to screen the cavy population for the presence of either Giardia or Cryptosporidium, and any other gastrointestinal, potential zoonotic parasite, given the importance of cavies in small scale farming in the country.

Positive cases of Giardia/Cryptosporidium infection were found, indicating that either Giardia or Cryptosporidium or both parasites occur in cavy husbandry in the country.

Among zoonotic parasites, the unicellular flagellate $G$. intestinalis (syn. Giardia duodenalis, Giardia lamblia, Lamblia lamblia) is known to cause gastroenteritis in its hosts. Molecular and phylogenetic analyses of G. duodenalis isolates identified eight distinct genetic groups (known as assemblages $\mathrm{A}-\mathrm{H}$ ), which differ in their host distribution $[28,29]$. Assemblages $A$ and $B$ are the zoonotic assemblages [30] associated with human and domestic animal infections [15]. As Assemblage B has been isolated in domestic cavies [15], the coproantigen Elisa positive result indicates that the domestic cavies could potentially play a role in the zoonotic transmission of

Table 1 Helminthe infections in domestic cavies in the western highland of Cameroon

\begin{tabular}{lllll}
\hline Helminthes & $\begin{array}{l}\text { Total number of } \\
\text { animals examined }\end{array}$ & $\begin{array}{l}\text { Number } \\
\text { positive }\end{array}$ & $\begin{array}{l}\text { Percentage } \\
(\%)\end{array}$ & $95 \% \mathrm{Cl}^{\mathrm{a}}$ \\
\hline $\begin{array}{l}\text { Paraspidodera } \\
\text { uncinata }\end{array}$ & 397 & 4 & 1 & $(0.3-2.7)$ \\
$\begin{array}{l}\text { Heligmosomoides } \\
\text { polygyrus }\end{array}$ & 397 & 1 & 0.3 & $(0.0-1.6)$ \\
$\begin{array}{l}\text { Trichuris sp } \\
\text { aCl: Confidence interval }\end{array}$ & 397 & 1 & 0.3 & $(0.0-1.6)$ \\
\hline
\end{tabular}

${ }^{a} \mathrm{Cl}$ : Confidence interval giardiasis in the region surveyed. Since giardiasis causes the infected cavies to become weak, moribund or dead [31], there is a possible threat to cavy industry in the country due to the economic harm that might be incurred following animal death and presence of disease. This is supported by complaints from farmers of fever, diarrhea and sudden death in cavies during past surveys [25]. To unveil the true status of giardiasis in domestic cavies in the country, follow-up studies are required to determine the species and the molecular isolate of the Giardia parasite present in cavies and human.

The zoonotic transmission of Cryptosporidium parasites between farm animals and humans is well documented [3, 5], with C. parvum regarded as the most important species occurring between humans and animals [5]. Previous studies to compare C. parvum from human and $C$. wrairi from domestic cavies showed very striking similarities and also differences on their infectivity in mice $[14,32]$. Though a previous study to resolve the controversy in the taxonomy of Cryptosporidium species showed that $C$. wrairi was not a species on its own but one of the genotypes of C. parvum [33], $C$. wrairi is now recognized as a separate species [34]. Whether C. wrairi is a genotype of the zoonotic C. parvum or a species on its own, it is a potential zoonotic protozoa since it has been documented in human and also in cattle [35]. Therefore, a zoonotic transmission of Cryptosporidum between human and domestic cavies is possible. Concerning cavy husbandry, coproantigen Elisa showed positive results, indicating that this parasite may be present. Since cryptosporidiasis in domestic cavies cause depression, anorexia, diarrhea, watery caecal contents, and death [12], there is a possibility of economic losses among cavy farmers. Again, this is supported by previous observations in cavy health during our previous survey [25]. As for Giardia, no conclusions could be drawn for Cryptosporidium until further studies are carried out to show that the genotypes from human and cavies isolates in the area are similar.

The test used for the detection of Cryptosporidium and Giardia (oo) cysts was coproantigen ELISA which detect the oo (cyst) antigen, rather than the (oo) cyst itself. Unlike serological tests which detect the antibodies to the pathogen, this test detects a parasite element, indicating a current infection. This test has the advantage of being more sensitive and simple in the detection of Cryptosporidium and Giardia than microscopy techniques. A negative result for Cryptosporidium and Giardia with the fecal flotation may be related to the flotation solution (Sodium Chloride) which is likely to distort the (oo) cysts, thus leading to a poor diagnosis of these parasites [27].

The fact that Giardia/Cryptosporidium positive samples were all from non-diarrheic individuals suggest that 
diarrheic stools in cavies might be due to other causes (bacteria, viruses, other parasites, feedstuff and others).

Three helminthe species were detected in the present study: P. uncinata, Heligmosomoides polygyrus (Syn. Nematospiroides dubius) and Trichuris sp. P. uncinata is a common parasite of domestic cavies which was reported in previous studies $[25,36]$, indicating that this parasite could be endemic in the area.

H. pygyrus (Syn. N. dubius) is not known to occur in cavies but is documented as a zoonotic parasite of rats and mice in North America and Europe [37]. Due to the common presence of mice and cavies in the household, the parasite is likely to be spurious in cavies. Nevertheless, since rats, mice and cavies are rodents, cavies stand as potential host for this zoonotic parasite. Until the adult worm is identified in domestic cavies, it will be risky to conclude on a parasite-host relationship between $H$. polygyrus (Syn. N. dubius) and cavies. The prevalence was quite low $(0.3 \%)$ suggesting that the transmission risk is low.

The genus Trichuris has been identified in wild cavies (Cavia apera aperea) in Peru [38] and in domestic cavies [39]. This genus occurs both in humans and animals but as this parasite was not identified to species level in this work, the zoonotic characteristic of the parasite cannot be discussed. In addition, the infection level was quite low $(0.3 \%)$ suggesting that the threat to human and cavy husbandry in the study area is also low.

\section{Conclusion}

Domestic cavies are a potential source of human giardiasis, cryptosporidiosis and infection with $H$. polygyrus (Syn. N. dubius) in the western highlands of Cameroon. The presence of Giardia and/or Cryptosporidium in cavies kept in the same living area with humans suggests that transmission of Giardia and Cryptosporidium between cavies and human is possible. Therefore, good hygiene practices are recommended during and after handling cavies or exposure to their feces. Similarly, living with cavies in the same household or living close to the keeping area as is the case with cavy farmers in the rural areas, should be avoided. These preventive measures are useful not only to control the parasites described in this study, but many other zoonotic agents occurring in cavies. Implementation of these measures will both protect cavy industry and public health. In keeping with the One Health Initiative, veterinarians and medical doctors should collaborate to address the problem of Giardia and Cryptosporidium infection in cavies and cavy keepers in Cameroon and other countries with a similar cavy production system. Follow-up studies are required to further taxonomically characterize these cavy parasites, and to determine their potential route of transmission to human.

\section{Additional file}

Additional file 1: Values in the table are the optical densities obtained from the analysis of fecal samples for the presence of Giardia/Cryptosporidium coproantigen. Values $\mathrm{A} 1$ and $\mathrm{B} 1$ refer to positive control while value $\mathrm{H} 12$ refers to negative control. (XLS $20 \mathrm{~kb})$

\section{Abbreviations}

BecA: Biosciences Eastern and Central Africa; CSIRO: Commonwealth Scientific and Industrial Research Organization - Australia; DFAT: Department of Foreign Affairs and Trade - Australia; ILRI: International Livestock Research Institute; $\mathrm{NaCl}$ : Sodium chloride

\section{Acknowledgements}

The authors give thanks to DFAT through ILRI-BecA-CSIRO and partnerships for funding the Project "Harnessing husbandry of domestic cavy for alternative and rapid access to food and income in Cameroon and the eastern Democratic Republic of the Congo" (Grant N CSI002-GUI) for financial support in acquiring the diagnostic kit. Thanks to all the farmers and West regional cavy innovation platforms stakeholders for participating. Mr. Tebug Tumasang Thomas is appreciated for his assistance with the laboratory work.

\section{Funding}

This work was partially funded by DFAT through ILRI-BecA-CSIRO (Grant N CSI002-GUI). The funder provided support to acquire the ELISA kit but did not play any role in the design of the study, collection, analysis, and interpretation of data and in writing the manuscript.

\section{Availability of data and materials}

All data analyzed during this study are included in this published article and its Additional file 1.

\section{Authors' contributions \\ MKK conceived and designed the study, participated in the field and laboratory work, led the statistical analysis and wrote the manuscript. FM participated in the study design, helped in the acquisition of funding and data, and critical revised the manuscript. TTN helped collect field data and carry out the laboratory work. EM critically revised the manuscript; JT and AT participated in the conception and design of the study. GT participated in the study design and critically revised the manuscript. All authors read and approved the final manuscript.}

\section{Competing interests}

The authors declare that they have no competing interests.

\section{Consent to publish}

Not applicable.

\section{Ethical approval}

This research did not involve experiments on animals. Feces and external parasites collected on animals were performed in accordance with all applicable international guidelines for the care of animals. Farmers accepted to participate in the study by granting oral informed consent, and allowed the collection of data from their cavies.

\section{Publisher's Note}

Springer Nature remains neutral with regard to jurisdictional claims in published maps and institutional affiliations.

\section{Author details}

${ }^{1}$ Department of Animal Production, Faculty of Agronomy and Agricultural Sciences, PO BOX 188, Dschang, Cameroon. ${ }^{2}$ Center for Research on Filariases and other Tropical Diseases (CRFilMT), P.O. Box 5797, Yaoundé, Cameroon. ${ }^{3}$ Department of Anatomy and Physiology of Farm Animals, Faculty of Animal Science and Aquaculture, Agricultural University of Athens, 75 lera Odos St, Votanikos, 11855 Athens, Greece. 
Received: 22 January 2016 Accepted: 6 June 2017

Published online: 26 June 2017

\section{References}

1. Taylor JP, Perdue JN, Dingley D, Gustafson TL, Patterson M, Reed LA. Cryptosporidiosis outbreak in a day-care centre. Am J Dis Child. 1985;139:1023-5.

2. Ogunsanya TI, Rotimi VO, Adenuga A. A study of the aetiological agents of childhood diarrhoea in Lagos. Nigeria J Med Microbiol. 1994;40:10-4.

3. Banda Z, Nichols RAB, Grimason AM, Smith HV. Cryptosporidium infection in non-human hosts in Malawi. Onderstepoort J Vet Res. 2009;76:363-75.

4. Brandonisio O. Waterborne transmission of Giardia and Cryptosporidium. Parassitologia. 2006:48:91-4.

5. Chalmers RM, Giles M. Zoonotic cryptosporidiosis in the UK - challenges for control. J Appl Microbiol. 2010;109:1487-97.

6. Smith H, Nichols RA. Zoonotic protozoa-food for thought. Parassitologia. 2006:48:101-4

7. Eberhard ML, Nace EK, Freeman AR. Survey for Cyclospora cayetanensis in domestic animals in an endemic area in Haiti. J Parasitol. 1999:85:562-3.

8. de la Cruz KD, Ribbeck R, Daugschies A. Occurrence and distribution of ectoparasites in guinea pigs (Cavia spp.) in Peru, South America. Berl Munch Tierarztl Wochenschr. 2003;116:102-7.

9. Yiva $\mathrm{CH}$, Fon DE, Meutchieye F, Niba AT, Manjeli Y, Djikeng A. Cavies for income generation, manure for the farm and meat for the table. Scholarly J Agric Sci. 2014;4:260-4

10. Cameroon, National Institute of Statistics. Annuaire statistique du Cameroun Recueil des séries d'informations statistiques sur les activités économiques, sociales, politiques et culturelles du pays jusqu'en 2013. http://www.stat.cm/ downloads/annuaire/2013/Annuaire_statistique_2013.pdf. Accessed 20 November 2015

11. Papenoc: Projet d'appui aux élevages non-conventionnels. Ministère de l'élevage, des pêches et des industries animales. Yaoundé, s.n.; 2010.

12. Angus KW, Hutchison G, Munro HM. Infectivity of a strain of Cryptosporidium found in the guinea-pig (Cavia porcellus) for guinea-pigs, mice and lambs. J Comp Pathol. 1985;95:151-65.

13. Chrisp CE, Reid WC, Suckow MA, Rush HR, Bush A, Thomann M. Cryptosporidiosis in guinea pigs: an animal model. Infect. Immun. 1990;58:674-9.

14. Chrisp CE, Suckow MA, Fayer R, Arrowood MJ, Healey MC, Sterling CR. Comparison of the host ranges and antigenicity of Cryptosporidium parvum and Cryptosporidium wrairi from Guinea pigs. J. PRO. 1992;39:406-9.

15. Lebbad M, Mattsson JG, Christensson B, Ljungström B, Backhans A, Andersson JO, et al. From mouse to moose: Multilocus genotyping of Giardia isolates from various animal species. Vet Parasitol. 2010;168:231-9.

16. Bueno I, Smith KM, Sampedro F, Machalaba CC, Karesh WB, Travis DA. Risk prioritization tool to identify the public health risks of wildlife trade: the case of rodents from Latin America. Zoonoses Public Health. 2015; doi:10.1111/zph.12228.

17. Visvesvara GS. Giardiasis in children. J Pediatr Gastroentrol Nutr. 1982;1:463-5.

18. Addiss DG. Evaluation of a commercially available enzyme-linked Immunoabsorbent assay for Giardia lamblia antigen in stool. J Clin Microbiol. 1991;29:1137-42.

19. Ajeagah G, Njine T, Foto S, Bilong Bilong CF. And. Karanis P. Enumeration of Cryptosporidium spp and Giardia spp (oo)cysts in a tropical eutrophic lake: the municipal lake of Yaounde. Int. J. Environ. Sci. Tech. 2007:4:223-32.

20. Richardson DJ, Callahan KD, Dondji B,Tsekeng P. Richardson KE. Prevalence of waterborne protozoan parasites in two rural villages in the West Province of Cameroon. Comp Parasitol 2011; 78: 180-184

21. Chia PN, Ukaga CN, Yongabi KA, Nwoke BEB, Tih PM. Baseline study on the occurrence of Cryptosporidium Spp from streams water, after torrential rains in Bamenda. Cameroon GJBAHS. 2015:4:62-9.

22. Bayemi PH, Bryant MJ, Perera BO, Mbanya JN, Cavestany D, Webb EC. Milk production in Cameroon: A review. Livestock Research for Rural Development. 2005; 17: 6. http://www.Irrd.org//rrd17/6/baye17060.htm Accessed 1 July 2015.

23. Nchinda VP, Mendi SD. Factors influencing the adoption of yoghurt technology in the Western Highlands Agroecological zone of Cameroon. Livestock Research for Rural Development, 2008; 20:7. http://www.Irrd.org//rrd20/7/nchi20102.htm Accessed 11 January 20162015.

24. Noordhuizen JPTM, Frankena K, van der Hoofd CM, Graat EAM. Application of quantitative methods in Veterinary parasitology. Wageningen, The Netherlands: Wageningen Pers; 1997.

25. Kouam MK, Meutchieye F, Nguafack TT, Miegoué E, Tchoumboué J, Theodoropoulos G. Parasitic fauna of domestic cavies in the western highlands of Cameroon (Central Africa). BMC Vet Res. 2015;11:288 doi:10.1186/s12917-015-0605-4.

26. Thienpont D, Rochette F, Vanpanrijs OFJ. Diagnostic de verminoses par examen coprologique. Beerse Belgique: Janssen Research Foundation; 1979.

27. Zajac AM, Conboy GA. Veterinary clinical parasitology. 7th ed. Ames, lowa, USA: Blackwell Publishing; 2006.

28. Monis P T. Cacciò S. M. Thompson R. C. Variation in Giardia: towards a taxonomic revision of the genus. Trends Parasitol 2009; 25: 93-100.

29. Takumi K, Swart A, Mank T, Lasek-Nesselquist E, Lebbad M, Cacciò SM, et al. Population-based analyses of Giardia duodenalis is consistent with the clonal assemblage structure. Parasit Vectors. 2012;5:168.

30. PantchevN, Broglia A, Paoletti B, Globokar Vrhovec M, Bertram A, Nöckler K Cacciò SM. Occurrence and molecular typing of Giardia isolates in pet rabbits, chinchillas, guinea pigs and ferrets collected in Europe during 2006-2012. Vet Rec 2014; doi:10.1136/vr.102236.

31. Fujinami F, Iwasaki HO. Giardiasis in guinea pigs: a case report. Jikken Dobutsu. 1984;33:361-3.

32. Tilley M, Upton SJ, Chrisp CE. A comparative study on the biology of Cryptosporidium sp. from guinea pigs and Cryptosporidium parvum (Apicomplexa). Can J Microbiol. 1991;37:949-52.

33. Xiao L, Escalante L, Yang C, Sulaiman I, Escalante AA, Montali RJ, et al. Phylogenetic analysis of Cryptosporidium parasites based on the smallsubunit rRNA Gene locus. Appl Environ Microbiol. 1999;65:1578-83.

34. Kváč M, Hofmannová L, Hlásková L, Kveto`nová D, Vítovec J, McEvoy J, et al. Cryptosporidium erinacei n. Sp. (Apicomplexa: Cryptosporidiidae) in hedgehogs. Vet. Parasitology. 2014;201:9-17.

35. Azami M, Moghaddam DD, Salehi R, Salehi M. The identification of Cryptosporidium species (protozoa) in Ifsahan, Iran by PCR-RFLP analysis of the 18S rRNA gene. Mol Biol (Mosk). 2007;41:934-9.

36. Payne VK, Ndah G, Ngwa F, Yamssi C, Megwi L, Fonteh AF, et al. Prevalence and intensity of infection of gastrointestinal parasites in cavies from Menoua division-west region of Cameroon. Jaeri. 2016;5:1-12.

37. Taylor MA, Coop RL, Wall RL. Veterinary parasitology. 3rd ed. Oxford: Blackwell publishing Ltd; 2007.

38. Dittmar K. Arthropod and helminth parasites of the wild guinea pig, Cavia aperea, from the Andes and the cordillera in Peru. South America J Parasitol. 2002:88:409-11.

39. García CJ, Chávez AV, Pinedo RV, Suárez FA. Gastrointestinal helminthiasis in guinea pig (Cavia porcellus) family-commercial breeding farms in Ancash. Peru rev inv. 2013;24:473-9.

\section{Submit your next manuscript to BioMed Central and we will help you at every step:}

- We accept pre-submission inquiries

- Our selector tool helps you to find the most relevant journal

- We provide round the clock customer support

- Convenient online submission

- Thorough peer review

- Inclusion in PubMed and all major indexing services

- Maximum visibility for your research

Submit your manuscript at www.biomedcentral.com/submit
) Biomed Central 